\title{
Anticancer activity of some polyamine derivatives on human prostate and breast cancer cell lines
}

\author{
Marta Szumilak ${ }^{1 凶}$, Malgorzata Galdyszynska² ${ }^{2}$ Kamila Dominska² ${ }^{2}$ Andrzej Stanczak ${ }^{1}$ and \\ Agnieszka Piastowska-Ciesielska2,3药
}

1Department of Hospital Pharmacy, Faculty of Pharmacy, Medical University of Lodz, Łódź, Poland; 2 Department of Comparative Endocrinology, Medical University of Lodz, Łódź, Poland; 'Laboratory of Cell Cultures and Genomic Analysis, Medical University of Lodz, Łódź, Poland

The aim of this study was to expand our knowledge about anticancer activity of some polyamine derivatives with quinoline or chromane as terminal moieties. Tested compounds were evaluated in vitro towards metastatic human prostate adenocarcinoma (PC3), human carcinoma (DU145) and mammary gland adenocarcinoma (MCF7) cell lines. Cell viability was estimated on the basis of mitochondrial metabolic activity using watersoluble tetrazolium WST1 to establish effective concentrations of the tested compounds under experimental conditions. Cytotoxic potential of polyamine derivatives was determined by the measurement of lactate dehydrogenase activity released from damaged cells, changes in mitochondrial membrane potential, the cell cycle distribution analysis and apoptosis assay. It was revealed that the tested polyamine derivatives differed markedly in their antiproliferative activity. Bischromane derivative 5 a exhibited a rather cytostatic than cytotoxic effect on the tested cells, whereas quinoline derivative 3 a caused changes in cell membrane integrity, inhibited cell cycle progression, as well as induced apoptosis of prostate and breast cancer cells which suggest its potential application in cancer therapy.

Key words: polyamine derivatives, prostate cancer, breast cancer, mitochondrial potential, cell cycle, apoptosis

Received: 24 August, 2016; revised: 21 December, 2016; accepted: 28 December, 2016; available on-line: 14 April, 2017

e-mail: marta.szumilak@umed.lodz.pl (MS - chemistry), agnieszka.piastowska@umed.lodz.pl (AP - in vitro biological evaluation) Abbreviations: DU145, human carcinoma; MCF7, mammary gland adenocarcinoma; PC3, metastatic human prostate adenocarcinoma

\section{INTRODUCTION}

Cancer is used as a general term describing a group of approximately 120 different diseases, which can affect various parts of the body. It can be also defined as the state characterized by uncontrolled cell proliferation and normal tissues invasion (Latosinska \& Latosinska, 2013). According to the Institute for Health Metrics and Evaluation (IHME) report, cancer is the second leading cause of death worldwide. Increased incidence of cancer observed in the developed countries can be attributed in part to the changes in demographic structure i.e. greater longevity of population, as well as risk factors like smoking, obesity and unhealthy diet (Fitzmaurice et al., 2015).

Prostate cancer $(\mathrm{PCa})$ has the highest incidence ratio and it is the second most common cause of death in men (Siegel et al., 2016). In Poland, in 2013, about 12 162 men received a prostate cancer diagnosis and an estimated 4281 men died of it (Dominska et al., 2012; Wojciechowska \& Didkowska, 2013). When surgery is excluded, the basic method of conservative treatment in cases of advanced cancer is hormonal therapy involving the elimination of endogenous androgens and the blockade of the androgen receptor. Hormonal therapy slows down the development of cancer but it does not lead to full recovery. After an initial period of improvement, the disease progression ensues due to the development of androgen independent cancer, followed by fully hormone resistant cancer. As aggressive, poorly-differentiated high-grade PCa is currently incurable and potentially lethal, there is a need for a new treatment strategy which can be provided by newly designed anticancer medicines (Siegel et al., 2013; Jemal et al., 2011; Walczak \& Carducci, 2007).

The second type of cancer cell line included in this study is derived from breast cancer, which is the most common female cancer worldwide (Wojciechowska \& Didkowska, 2013; Siegel et al., 2016). In Poland, in 2013, about 17142 women received a breast cancer diagnosis and it is estimated that 5816 women died of the disease. Some breast cancers rapidly develop multidrug resistance to chemotherapy medicines which results in therapeutic failure (Li et al., 2015). Aforementioned data indicate that the search for novel, effective and less toxic anticancer agents is very important goal for contemporary medicine (Ma \& Adjei, 2009).

Our quest for potential anticancer agents is focused on symmetrical polyamine derivatives with bicyclic terminal moieties designed according to bisintercalators' structural requirements (Szulawska-Mroczek et al., 2013; Szumilak et al., 2010). Bisintercalators are able to interact reversibly with double stranded (dsDNA) by simultaneous insertion of two chromophores usually tethered by a polyamine linker. It results in higher DNA affinity and sequence selectivity in comparison to corresponding monointercalating agents (Brana et al., 2001; Lorente et al., 2004; Tse \& Boger 2004). In addition, a positive correlation between cytotoxic potency and the strength of reversible DNA binding for bisintercalators has been observed (Taher \& Hegazy, 2013).

Our previous studies involving synthesis and biological in vitro evaluation of polyamine derivatives with various bicyclic moieties, revealed that polyamine derivatives with quinoline $\mathbf{3 a}$ and chromane $\mathbf{5 a}$ scaffolds (Fig. 1) are the most promising entities exhibiting antiproliferative activity toward a highly aggressive melanoma cell line A375 (Szulawska-Mroczek et al., 2013; Szumilak et al., 2010). Although the chemical structure of $\mathbf{5 a}$ was formerly known as a chelating agent (Trathnigg et al., 1985), we have obtained it by another route and assessed its 
A

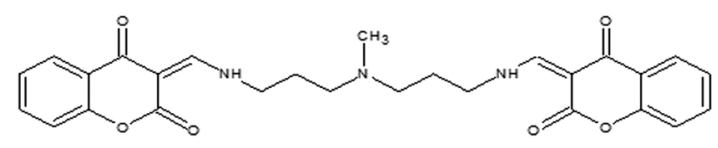

B<smiles>Cc1c(C(=O)NCCCC=NCCCNC(=O)c2cnc3ccccc3c2C)ccc2ccccc12</smiles>

Figure 1. Chemical structure of $3 a N_{,} N^{\prime}$-(piperazine-1,4-diyl-dipropane-3,1-diyl)bis(4-aminoquinoline-3-carboxamide) and 5a $N, N^{\prime}$-[(methylimino)dipropane-3,1-diyl]bis[3-(aminomethylene) chroman-2,4-dione] (Szumilak et al., 2010; Trathnigg et al., 1985; Szulawska-Mroczek et al., 2013).

antiproliferative activity together with other chromone/ chromane derivatives designed as potential bisintercalators (Szulawska-Mroczek et al., 2013).

Taking into consideration that prostate cancer in men and breast cancer in women belong to the most frequently registered malignant cancers (Siegel et al., 2016), we decided to evaluate the influence of $\mathbf{3} \mathbf{a}$ and $\mathbf{5 a}$ on well-described prostate and breast cancer cell lines that are commonly used as models of drug susceptibility: PC3, DU145 and MCF7 (Sampson et al., 2013; Ellem et al., 2014; Li et al., 2015; Ming et al., 2015). The aforementioned choice can be supported by studies reporting that quinoline ring system is used in many anticancer agents (Burns et al., 2002; Deady et al., 1997; Hansch \& Verma, 2007; Li et al., 2016; Rescifina et al., 2014) and chromane derivatives possess promising anticancer activity toward breast cancer (Rawat et al., 2016) and leukaemia (Nawrot-Modranka et al., 2006) or prevent progression to a metastatic phenotype for human prostate cancer (Xu et al., 2010).

\section{MATERIALS AND METHODS}

Examined compounds. N,N'-(piperazine-1,4-diyldipropane-3,1-diyl)bis(4-aminoquinoline-3-carboxamide) $3 \mathrm{a}$ as hydrochloride and N,N'-[(methylimino)dipropane3,1-diyl]bis[3-(aminomethylene)chroman-2,4-dione] 5a (Fig. 1) used in this study, were chosen from previously synthesized and in vitro evaluated polyamine derivatives. Their synthesis and analytical data were described earlier (Szumilak et al., 2010; Trathnigg et al. 1985, Szulawska-Mroczek et al., 2013). Both substances were dissolved immediately before the experiment at concentrations ranging from $5 \mu \mathrm{M}$ to $50 \mu \mathrm{M}$ for $3 \mathrm{a}$ and $5 \mu \mathrm{M}$ to $90 \mu \mathrm{M}$ for $\mathbf{5 a}$. Untreated cells were used as a control.

Cell culture. Metastatic human prostate adenocarcinoma cell line PC3 (American Type Culture Collection, ATCC ${ }^{\circledR}$ CRL-1435 ${ }^{\mathrm{TM}}$ ) and mammary gland adenocarcinoma cell line MCF7 (European Collection of Cell Culture, ECACC ${ }^{\circledR}$ 86012803) were maintained in RPMI1640 medium. Human carcinoma cell line DU145 (American Type Culture Collection, ATCC ${ }^{\circledR} \mathrm{HTB}^{\mathrm{TM}}{ }^{\mathrm{TM}}$ was maintained in DMEM. Both media were supplemented with $10 \%(v / v)$ heat-inactivated Foetal Bovine Serum (FBS) (Thermo Fisher Scientific Inc/Life technologies). The cells were cultured at $37^{\circ} \mathrm{C}$ under a humidified atmo- sphere with $5 \% \mathrm{CO}_{2}$. Before each experiment, the cells were deprived of serum for $24 \mathrm{~h}$.

Cell viability - mitochondrial metabolic activity. Cell viability was estimated on the basis of mitochondrial metabolic activity using WST1 (disodium mono\{4-[3(4-iodophenyl)-2-(4-nitrophenyl)-2H-tetrazol]-3-ium-5-yl] benzene-1,3-disulfonate $\}$ ) assay as described elsewhere (Piastowska-Ciesielska et al., 2013). PC3, DU145 and MCF7 cells were seeded on 96-well plates at a density of $1 \times 10^{4}$ per well. After $24 \mathrm{~h}$, the culture medium was replaced by an experimental one with desired concentrations of compounds and treated for 24 or $48 \mathrm{~h}$. Following incubation, $10 \mu \mathrm{l}$ of WST1 reagent was added and plate was incubated for further $4 \mathrm{~h}$. The spectrophotometric absorbance of each well was measured at $450 \mathrm{~nm}$ using ELX808IU plate reader (BioTeck). The same procedure was repeated 14 days after the initial dissolution of compounds. Relative cell viability (\%) was expressed as a percentage relative to untreated control cells. $\mathrm{IC}_{50}$ - concentration leading to $50 \%$ reduction in cell viability, compared to untreated control, was determined from the sigmoidal curve obtained by plotting the percentages of cell viability relative to the control versus logarithmic concentration of compounds using a non-linear regression analysis (Saleh et al., 2015). On the basis of WST1 results, effective concentrations of $\mathbf{3 a}$ and $\mathbf{5 a}$ (for each cell line) were chosen for use in the remaining experimental assays.

Cell damage - Lactate Dehydrogenase (LDH) Leakage Assay. Cytotoxic potential of polyamine derivatives was measured using Cytotoxicity Detection Kit PLUS (LDH) (Roche) which allows the activity of lactate dehydrogenase released from damaged cells to be measured. Briefly, cells grown in 96-well plates at a density of $7 \times 10^{3}$ per well were treated with compounds $3 \mathbf{a}$ or 5a for $48 \mathrm{~h}$. After incubation, LDH assay was performed according to the manufacturer's protocol. The absorbance of each well was measured at $490 \mathrm{~nm}$ and $690 \mathrm{~nm}$ as a reference, using ELX808IU plate reader (BioTeck). $\mathrm{LDH}$ leakage was calculated using the following function: $\mathrm{LDH}$ leakage $(\%)=100 \times(\mathrm{CS}-\mathrm{BC}) /(\mathrm{NDC}-\mathrm{BC})$. CS, $\mathrm{BC}$ and NDC refer to absorption of the culture supernatant, the background control and the undamaged control, respectively.

Mitochondrial membrane potential. Changes in mitochondrial membrane potential were determined with Muse $^{\mathrm{TM}}$ Mitopotential Kit (Merck Millipore) which measures the accumulation of dye within the inner membrane of intact mitochondria. Briefly, cells grown in 6-well plates (at a density of $2.5 \times 10^{5}$ per well) were treated with $\mathbf{3 a}$ or $\mathbf{5 a}$. After $48 \mathrm{~h}$ of incubation, cells were collected by trypsinization, resuspended in media and counted. All samples were prepared according to the manufacturer's protocol and measured on Muse ${ }^{\mathrm{TM}}$ Cell Analyzer (Merck Millipore) according to manufacturer's instruction, standardized to control probes.

Cell cycle analysis. The cell cycle distribution analysis was performed with Guava ${ }^{\circledR}$ easyCyte (Merck Millipore) using FlowCellect ${ }^{\mathrm{TM}}$ Bivariate Cell Cycle Kit for G2/M Analysis kit (Merck Millipore). Cells were cultured on cell-culture dish at a density of $1 \times 10^{6}$ for $24 \mathrm{~h}$, after which they were treated with $3 \mathrm{a}(20 \mu \mathrm{M}$ for all cell lines) and 5a (5 $\mu \mathrm{M}$ for MCF7, $10 \mu \mathrm{M}$ for PC3 and 25 $\mu \mathrm{M}$ for DU145) for $48 \mathrm{~h}$. After incubation, cells were harvested and counted. Samples were prepared according to the manufacturer protocol and then measured on Guava $^{\circledR}$ easyCyte (Merck Millipore).

Quantification of apoptosis. Apoptosis was examined using Muse ${ }^{\mathrm{TM}}$ Annexin V \& Dead cell Kit (Merck 

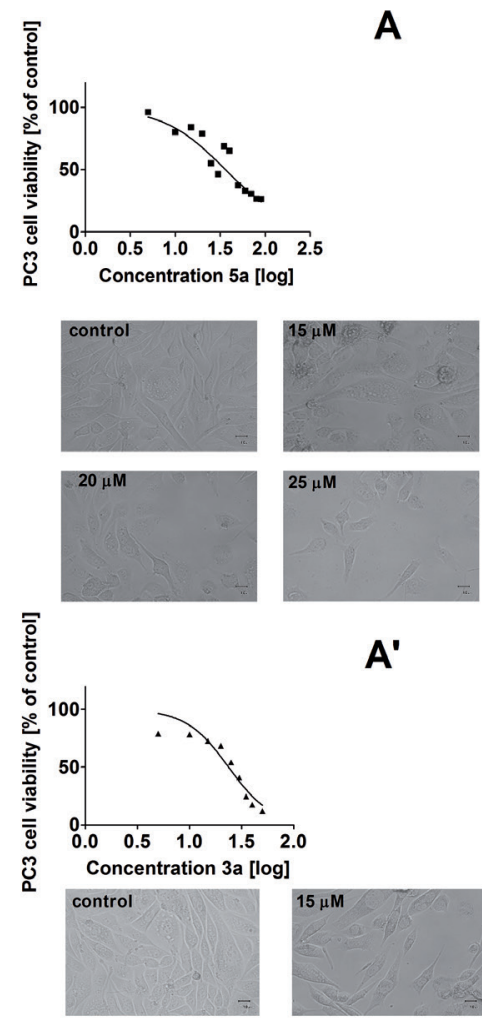

$A^{\prime}$
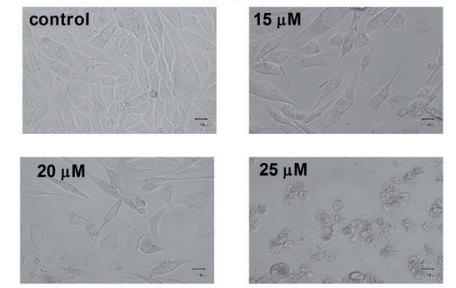

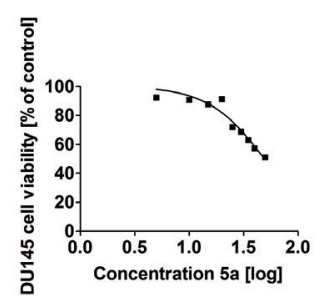

B
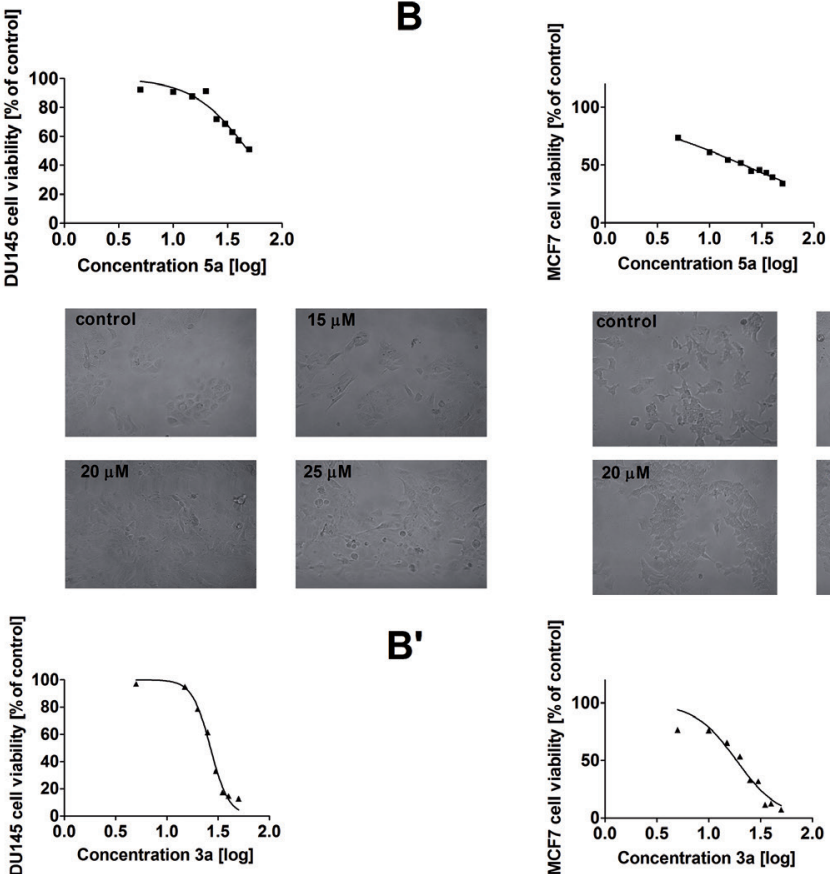

B'
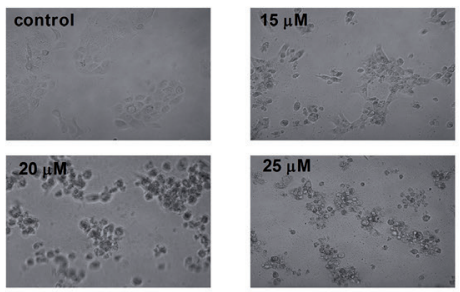
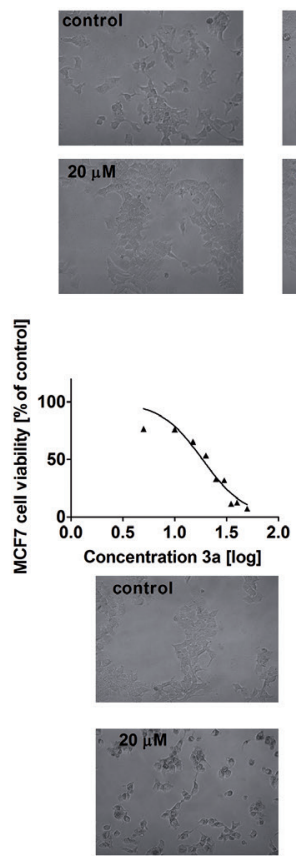

$C^{\prime}$

C
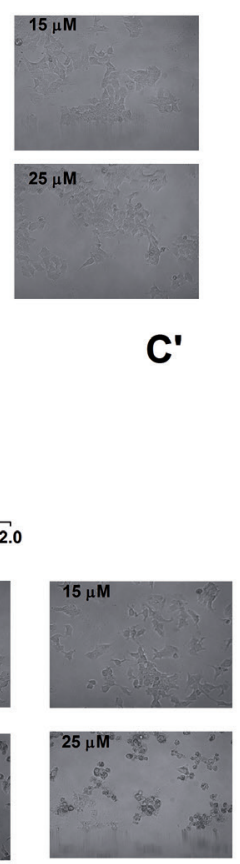

Figure 2. Polyamine derivative 3a containing quinoline moiety $(A-C)$ and polyamine derivative 5 a containing chromane moiety $\left(A^{\prime}-\right.$ $\left.C^{\prime}\right)$, inhibit the growth of human cancer cells.

The sigmoidal curve was obtained by plotting the percentages of cell viability relative to the control against the logarithmic concentration of compounds using non-linear regression analysis. The phase-contrast micrographs (lower panel) represent cells treated with $\mathbf{3 a}$ and $5 \mathbf{a}(15 \mu \mathrm{M}, 20 \mu \mathrm{M}$ and $25 \mu \mathrm{M})$ and untreated cells (control) which were cultured on serum-free medium. Photomicrographs were taken at a magnification of $\times 400$ (Olympus CKX41 with digital camera Olympus DP20) from representative experiments.

Millipore). Cells were cultured on 6-well plates at a density of $2.5 \times 10^{5}$ for $24 \mathrm{~h}$, after which they were treated with compound $\mathbf{3 a}$ or $\mathbf{5 a}$ for $48 \mathrm{~h}$. After treatment, cells were collected and incubated with Annexin V and 7-aminoactinomycin D (7AAD), a dead cell marker, for 20 min at room temperature in the dark. All samples were measured using Muse ${ }^{\mathrm{TM}}$ Cell Analyzer (Merck Millipore).

Statistical analysis. Results were expressed as means of results from a minimum of three independent experiments with similar patterns. $\mathrm{IC}_{50}$ was estimated from the sigmoidal curve obtained by plotting the percentages of cell viability relative to the control versus logarithmic concentration of compounds using non-linear regression analysis. Statistical analysis was performed using one-way ANOVA. All calculations were performed using GraphPad Prism 6 software (GraphPad Software, San Diego, California, USA). A p-value below 0.05 was considered statistically significant. All experiments were performed as three independent repetitions.

\section{RESULTS}

\section{Compounds' stability in cell culture media}

The influence on cancer cell viability of $\mathbf{3 a}$ and $\mathbf{5 a}$ immediately after initial dissolution (TO) and after 14 days
(T14) was compared to determine the compounds' stability. A decrease in cell viability after treatment with $\mathbf{5 a}$ was denoted after both incubation times (24 and $48 \mathrm{~h}$ ) for T0 and T14 as well. However, 5a at $50 \mu \mathrm{M}$, decreased the cell viability by $50 \%$ in PC3 cells at T0 $(24 \mathrm{~h}$ incubation), but only by $31 \%$ at T14. Similar results were observed after $48 \mathrm{~h}$ of incubation (data not shown). Furthermore, the ability of compound $3 \mathbf{a}$ to inhibit cancer cell viability fell 14 days after dissolution. For example, after $24 \mathrm{~h}$ of incubation with compound $3 \mathrm{a}$ at $25 \mu \mathrm{M}$, a $45 \%$ decrease in cell viability was observed at T0, but only $21 \%$ at T14. No significant difference between the results of 24 and $48 \mathrm{~h}$ of incubation for each time point was noticed. Therefore, both compounds were dissolved immediately before each experiment and a $48 \mathrm{hr}$ incubation period was used.

Influence of compounds on cancer cells - determination of $\mathbf{I C}_{50}$. Water-soluble tetrazolium (WST1) was used to assess the influence of compounds $3 \mathrm{a}$ and 5a on cell viability of prostate and breast cancer cells (measured via mitochondrial metabolic activity). The assay is based on WST1, a highly sensitive tetrazolium that produces soluble formazan via the NADPH oxidase reduction in mitochondria. The amount of formazan dye yielded, directly correlates to the number of metabolically-active live cells in the culture (Xiong et al., 2015). As before, in the first step, a concentration response course 

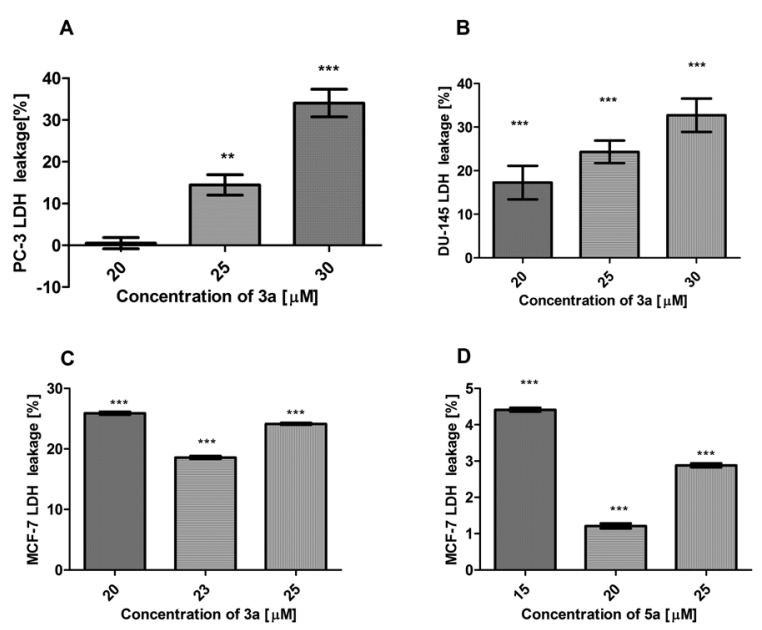

Figure 3. Polyamine derivative 3 a containing quinoline moiety increases LDH activity in PC3 (A), DU145 (B) and MCF7 (C) cell lines.

Polyamine derivative 5 a containing chromane moiety increases LDH activity in the MCF7 (D) cell line. All data is the mean of three independent experiments $\left({ }^{*} p<0.05 ;{ }^{* *} p<0.01 ;{ }^{* * *} p<0.001\right)$.

analysis was performed to determine the compounds' concentration required to inhibit the growth of cancer cells by $50 \%\left(\mathrm{IC}_{50}\right)$ after $48 \mathrm{~h}$ of incubation (Szumilak et al., 2010). Compounds $\mathbf{3} \mathbf{a}$ and $\mathbf{5 a}$ were tested in a wide range of concentrations from $5 \mu \mathrm{M}$ to $90 \mu \mathrm{M}$. Treatment of prostate and breast cancer cells with examined compounds resulted in concentration-dependent inhibition of cell mitochondrial activity which corresponded to cell viability (Fig. 2). $\mathrm{IC}_{50}$ values for compound 3a were found to be $23.70 \mu \mathrm{M}$ for PC3, $26.64 \mu \mathrm{M}$ for DU145 and $18.54 \mu \mathrm{M}$ for MCF7. Chromane derivative 5a exhibited a lower inhibitory activity than the quinoline one (3a) which is illustrated by following the $\mathrm{IC}_{50}$ values: $36.19 \mu \mathrm{M}, 49.20 \mu \mathrm{M}$ and $21.39 \mu \mathrm{M}$ for PC3, DU145 and MCF7, respectively.

\section{Effect of compounds on cancer cell lactate dehydrogenase leakage and mitochondrial membrane potential}

The effect of $\mathbf{3} \mathbf{a}$ and $\mathbf{5} \mathbf{a}$ on lactate dehydrogenase activity in all cancer cell lines was determined by LDH assay. Results of LDH leakage after treatment with $\mathbf{3 a}$ and 5a at various concentrations are shown in Fig. 3.

LDH leakage significantly increased after treatment with $3 \mathrm{a}$ as compared to control $(p<0.05)$. It depended on the compound's concentration and cancer type. The highest level of LDH leakage was observed in PC3 and DU145 prostate cancer cell lines following treatment with compound $3 \mathrm{a}$ at $30 \mu \mathrm{M}(p<0.05)$ (Fig. 3A, B). In case of compound $\mathbf{5 a}, \mathrm{LDH}$ leakage was observed only for DU145 at the concentration of $50 \mu \mathrm{M}$ (data not shown) and MCF7 at all tested concentrations (Fig. 3D). The toxicity of compounds $\mathbf{3 a}$ and $\mathbf{5 a}$ was further evaluated by microphotographs, which demonstrated that cells treated with 3 a decreased in size and density and exhibited increased cellular damage (Fig. 2A-C, lower panel). In addition, a significantly higher number of PC3 cells with depolarized mitochondria was observed after their exposure to 3a (at indicated concentrations), as compared to non-treated cells (Table 1). This observation was not confirmed for DU145 and MCF7 cell lines. Compound 5a did not induce morphological changes in any tested cell line (Fig. 2A'-C').
Table 1. The effect of polyamine derivative 3 a containing quinoline moiety on depolarization of the mitochondrial membranes in PC3 cells. Results are presented as the percentage of cells compared to untreated cells.

\begin{tabular}{llll}
\hline & $20 \mu \mathrm{M}$ & $25 \mu \mathrm{M}$ & $30 \mu \mathrm{M}$ \\
\hline Live (LR) & $59.66 \pm 1.59$ & $52.87 \pm 3.64$ & $52.91 \pm 2.04$ \\
\hdashline $\begin{array}{l}\text { Depolarized/Live } \\
\text { (LL) }\end{array}$ & $10.93 \pm 0.65$ & $11.37 \pm 1.46$ & $16.52 \pm 0.50$ \\
\hdashline $\begin{array}{l}\text { Depolarized/Dead } \\
\text { (UL) }\end{array}$ & $29.19 \pm 1.12$ & $35.61 \pm 2.39$ & $30.31 \pm 1.66$ \\
\hline Dead (UR) & $0.22 \pm 0.05$ & $0.15 \pm 0.04$ & $0.27 \pm 0.05$ \\
\hline
\end{tabular}

Influence of compounds on cell cycle and apoptosis of cancer cells

To gain insight into the cytotoxic mechanism of action of compounds $3 \mathrm{a}$ and $5 \mathrm{a}$, their influence on the cell cycle was assessed. DNA analysis based on PI-based staining of DNA content and Anti-phospho-Histone H3 (Ser10) antibody was used to discriminate and measure the percentage of cells in each cell cycle phase (G1, S, G2 and M). The cell cycle analysis confirmed that cell treatment with 3 a resulted in cell cycle perturbation for all cancer cell lines. In untreated cells, a predominant number of cancer cells accumulated in the G1 phase. Compound $3 \mathrm{a}$ caused a reduction in the number of cells in the G1 phase and induced a cell population shift to the $\mathrm{S}$ phase of the cell cycle. This effect was clearly visible in DU145 cells treated with $3 \mathrm{a}$ at $20 \mu \mathrm{M}$ (Fig. 4B). A discreet accumulation of cells in the G2 phase was also observed.

In turn, PC3 and MCF7 cells exposed to the chromane derivative $\mathbf{5 a}$ at the concentration of $10 \mu \mathrm{M}$ and $5 \mu \mathrm{M}$, respectively, started to accumulate in the $\mathrm{M}$ phase (Table 2).

Programmed cell death can be initiated by several pathways. To determine whether the antiproliferative effect of both compounds can trigger cell apoptosis, DNA was stained with Annexin V and 7AAD. Apoptosis was induced in all cancer cells exposed to compound $\mathbf{3} \mathbf{a}$ at a concentration in the range from $20 \mu \mathrm{M}$ to $30 \mu \mathrm{M}$. However, the greatest increase in the amount of early apoptotic cells (LR) was observed in prostate cancer (Fig. 5). The exposure of prostate and breast cancer cells to compound $5 \mathrm{a}$ did not induce apoptosis in any significant manner (data not shown).

\section{DISCUSSION}

The search for new compounds targeting breast and prostate cancer is extremely important, due to their high incidence rates (Siegel et al., 2016; Wojciechowska

Table 2. The effect of polyamine derivative 5 a containing chromane moiety, on cell cycle distribution of PC3 cells. Results are presented as the percentage of treated cells when compared to untreated cells.

\begin{tabular}{lcccc}
\hline & $10 \mu \mathrm{M}(\mathrm{G} 1)$ & $10 \mu \mathrm{M}(\mathrm{S})$ & $10 \mu \mathrm{M}(\mathrm{G} 2)$ & $10 \mu \mathrm{M}(\mathrm{M})$ \\
\hline PC3 & $95.98 \pm 2.41$ & $88.61 \pm 3.95$ & $138.1 \pm 1.08$ & $204.8 \pm 2.61$ \\
\hline DU145 & $100.9 \pm 2.43$ & $102.8 \pm 2.91$ & $84.89 \pm 3.44$ & $47.23 \pm 1.67$ \\
\hline MCF7 & $97.89 \pm 3.0$ & $95.55 \pm 3.45$ & $107.8 \pm 1.64$ & $114.2 \pm 4.62$ \\
\hline
\end{tabular}



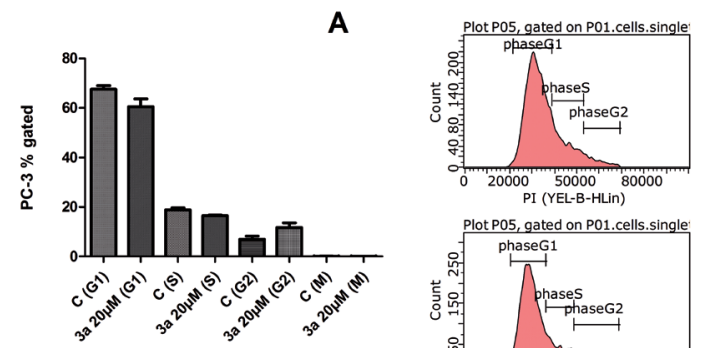

$A^{\prime}$

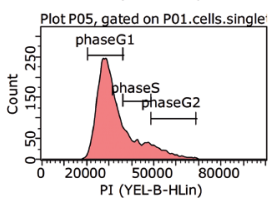

B
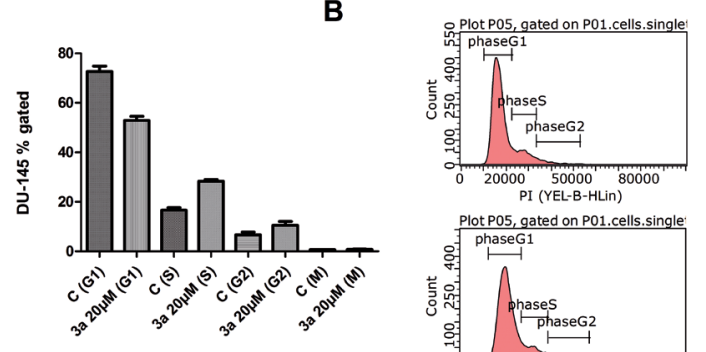

B'

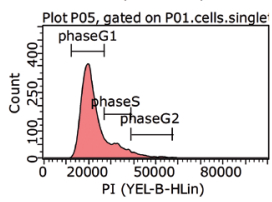

C
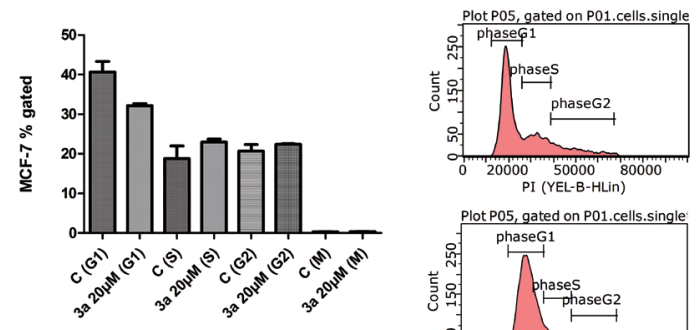

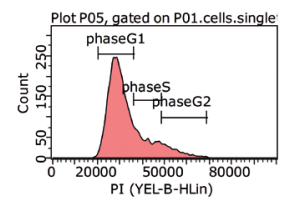

Figure 4. The effect of compound 3a on cell cycle distribution. DNA content measurement by Guava ${ }^{\circledR}$ easyCyte after $48 \mathrm{~h}$ of treatment. (A-C) data from three independent experiments; $\left(\mathbf{A}^{\prime}-\right.$ $\left.\mathbf{C}^{\prime}\right)$ representative histograms: higher panel - untreated $(\mathbf{C})$, lower panel - treated cells ( $3 \mathbf{a}$ at $20 \mu \mathrm{M})$.

\& Didkowska, 2013), as well as rapid development of multidrug resistance to chemotherapies, which block effective, life-saving therapies ( $\mathrm{Li}$ et al., 2015; Walczak \& Carducci, 2007).

As it was previously demonstrated, polyamine derivatives structurally related to known bisintercalators containing the quinoline $\mathbf{3 a}$ and chromane $\mathbf{5 a}$ moieties as terminal scaffolds, exhibit antiproliferative activity on a human melanoma cell line A375 (Szumilak et al., 2010), but the influence of these compounds on breast and prostate cancer has not been studied yet.

The results of current screening revealed significant differences in the anticancer activity of the examined compounds depending on a cancer cell line. Compound 5a was found to exhibit antiproliferative activity at a lower concentration in MCF7 $(21 \mu \mathrm{M})$ in comparison to PC3 and DU145 cell lines $(36 \mu \mathrm{M}$ and $49 \mu \mathrm{M}$, respectively) (Fig. 2). However, it had no significant influence on the lactate dehydrogenase leakage or mitochondrial membrane depolarization which may suggest its limited anticancer properties. Our present findings also confirmed that the compound $3 \mathrm{a}$ exhibited anticancer activity against prostate and breast cancer cells. Inhibition of mitochondrial activity was directly connected with the increase of the compound concentration. Estimated $\mathrm{IC}_{50}$ values for PC3, DU145 and MCF7 cancer cells ranged

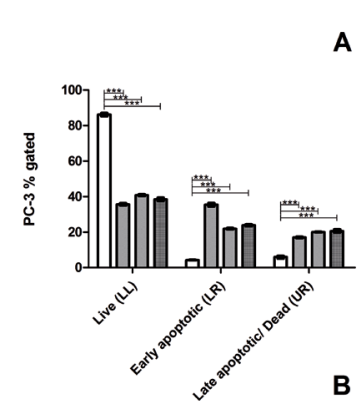

A
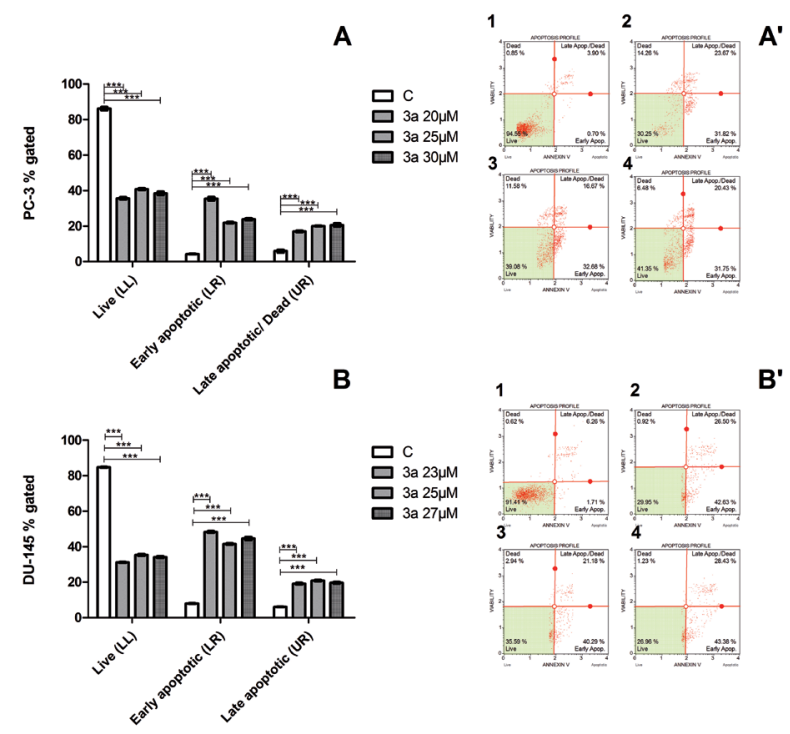

B'
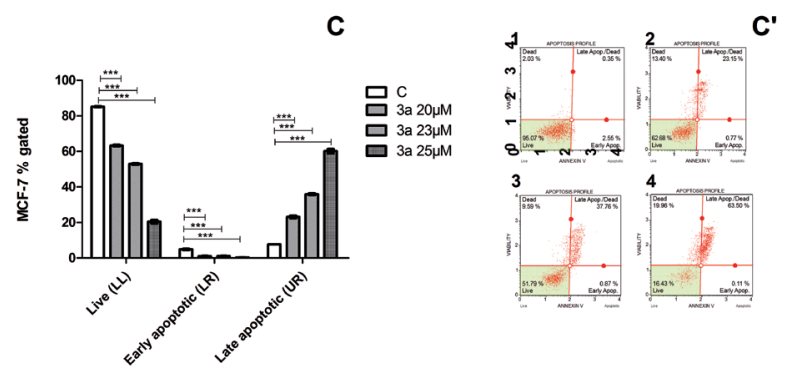

Figure 5. Cell apoptosis analysis of human prostate and breast cancer cell lines after $48 \mathrm{~h}$ treatment with compound $3 \mathrm{a}$ at different concentrations.

(A-C) data from three independent experiments: A: PC3 cell line, B: DU145 cell line and C: MCF7 cell line. The data is given as means of three independent experiments $\left({ }^{*} p<0.05\right.$; ${ }^{* *} p<0.01$; $\left.{ }^{* * *} p<0.001\right)$. Representative histograms: $A^{\prime}: 1$, untreated (C); $2: 20$ $\mu \mathrm{M}, 3: 25 \mu \mathrm{M}, 4: 30 \mu \mathrm{M}$; B': 1, untreated (C); 2: $23 \mu \mathrm{M}, 3: 25 \mu \mathrm{M}, 4$ : $27 \mu \mathrm{M} ; \mathrm{C}^{\prime}, 1$ : untreated (C), 2: $20 \mu \mathrm{M}, 3: 23 \mu \mathrm{M}, 4: 25 \mu \mathrm{M}$.

from $18 \mu \mathrm{M}$ to $27 \mu \mathrm{M}$ (Fig. 2). Furthermore, in contrast to the chromane derivative $5 \mathrm{a}$, the quinoline one (3a) caused changes in cell membrane integrity, as evidenced by increased lactate dehydrogenase leakage which correlated with mitochondrial membrane depolarization in the PC3 line (Table 1, Fig. 3).

To expand our knowledge about possible cytotoxic mechanism of action of the tested compounds, their effect on the cell cycle progression in breast and prostate cancer cells was examined. Compound $\mathbf{5 a}$ applied at the concentration approaching $\mathrm{IC}_{50}$ was found to have no statistically significant influence on changes in the prostate cancer cell cycle. In the examined prostate cell line, compound $\mathbf{5 a}$ was not able to decrease the number of cells in the G1, G2 or M phases, but an accumulation of cells in the $\mathrm{S}$ phase of the cell cycle was observed. However, when applied at the concentration needed for cell viability reduction to $60 \%(10 \mu \mathrm{M})$, compound 5 a was responsible for changes in the number of PC3 cells in the G1, S, G2/M phases, and the increase of cell number in the G2 and M phases of the cell cycle (Table 2).

Compound 3a strongly affected changes in the cell cycle progression. Most of the cells from untreated PC3, DU145 and MCF7 lines accumulated in the G1 phase. In contrast, compound $\mathbf{3 a}$ induced a noticeable reduction in the number of cells in the G1 phase and the 
displacement of cells in the $\mathrm{S}$ and $\mathrm{G} 2 / \mathrm{M}$ phases. The exposure of DU145 cells to 3 a resulted in the greatest accumulation of cells in the $\mathrm{S}$ rather than the $\mathrm{G} 2 / \mathrm{M}$ phase. However, the treatment of PC3 and MCF7 cells with 3a led to predominant distribution of cells in the G2/M phase (Fig. 4).

The expected anticancer feature of any potential drug is induction of cancer cell apoptosis. In case of the examined compounds, this effect is not unequivocal. Compound $\mathbf{5 a}$ was unable to significantly induce apoptosis, while compound $\mathbf{3 a}$ induced programmed cell death in the prostate and breast cancer cell lines in a significant manner. As shown in Fig. 5, the greatest increase in the amount of early apoptotic cells (LR) was observed in prostate cancer. Our findings are in accordance with other studies, showing that quinoline derivatives are capable of inducing apoptosis by an intrinsic pathway which involves depolarization of mitochondria together with disruption of their membranes (Sahu et al., 2013; Saleh et al., 2015a,b).

\section{CONCLUSION}

The work presented here describes anticancer activity of polyamine derivatives with quinoline $3 \mathrm{a}$ and chromane 5a scaffolds, on human prostate and breast cancer cell lines. The observed differences in antiproliferative activity of the examined compounds were significant and depended on the cancer cell line. Bischromane derivative $\mathbf{5 a}$ exhibited a rather cytostatic than cytotoxic effect, whereas the quinoline derivative 3 a changed the cell membrane integrity, as well as inhibited the growth of prostate and breast cancer by apoptosis. In addition, it has caused inhibition of cell cycle progression which suggests its potential application in the cancer therapy.

\section{Conflicts of interests}

The authors declare that they have no competing interests.

\section{Acknowledgements}

This work was supported by the Medical University of Lodz grants 503/0-078-04/503-01-004 and 502-03/3011-03/502-34-036

\section{REFERENCES}

Brana MF, Cacho M, Gradillas A,de Pascual-Teresa B, Ramos A (2001) Intercalators as anticancer drugs. Curr Pharm Des 7: 1745-1780. http://dx.doi.org/10.2174/1381612013397113

Burns MR, LaTurner S, Ziemer J, McVean M, Devens B, Carlson CL, Graminski GF, Vanderwerf SM, Weeks RS, Carreon J (2002) Induction of apoptosis by aryl-substituted diamines: role of aromatic group substituents and distance between nitrogens. Bioorg Med Chem Lett 12: 1263-1267. http://dx.doi.org/10.1016/S0960894X(02)00156-7

Deady LW, Kaye AJ, Finlay GJ, Baguley BC, Denny WA (1997) Synthesis and antitumor properties of $\mathrm{N}$-[2-(dimethylamino)ethyl]carboxamide derivatives of fused tetracyclic quinolines and quinoxalines: a new class of putative topoisomerase inhibitors. J Med Chem. 40: 2040-2046. http://dx.doi.org/10.1021/jm970044r

Dominska K, Piastowska-Ciesielska AW, Lachowicz-Ochedalska A, Ochedalski T (2012) Similarities and differences between effects of angiotensin III and angiotensin II on human prostate cancer cell migration and proliferation. Peptides 37: 200-206. http://dx.doi. org/10.1016/j.peptides.2012.07.022

Ellem SJ, De-Juan-Pardo EM, Risbridger GP (2014) In vitro modeling of the prostate cancer microenvironment. Adv Drug Deliv Rev 79-80: 214-221. http://dx.doi.org/10.1016/j.addr.2014.04.008

Fitzmaurice C, Dicker D, Pain A, Hamavid H, Moradi-Lakeh M, MacIntyre MF, Allen C, Hansen G, Woodbrook R, Wolfe C, Hamadeh RR, Moore A, Werdecker A, Gessner BD, Te Ao B, McMahon B,
Karimkhani C, Yu C, Cooke GS, Schwebel DC, Carpenter DO, Pereira DM, Nash D, Kazi DS, De Leo D, Plass D, Ukwaja KN, Thurston GD, Yun Jin K, Simard EP, Mills E, Park EK, CataláLópez F, deVeber G, Gotay C, Khan G, Hosgood HD 3rd, Santos IS, Leasher JL, Singh J, Leigh J, Jonas JB, Sanabria J, Beardsley J, Jacobsen KH, Takahashi K, Franklin RC, Ronfani L, Montico M, Naldi L, Tonelli M, Geleijnse J, Petzold M, Shrime MG, Younis M, Yonemoto N, Breitborde N, Yip P, Pourmalek F, Lotufo PA, Esteghamati A, Hankey GJ, Ali R, Lunevicius R, Malekzadeh R, Dellavalle R, Weintraub R, Lucas R, Hay R, Rojas-Rueda D, Westerman R, Sepanlou SG, Nolte S, Patten S, Weichenthal S, Abera SF, Fereshtehnejad SM, Shiue I, Driscoll T, Vasankari T, Alsharif U, Rahimi-Movaghar V, Vlassov VV, Marcenes WS, Mekonnen W, Melaku YA, Yano Y, Artaman A, Campos I, MacLachlan J, Mueller U, Kim D, Trillini M, Eshrati B, Williams HC, Shibuya K, Dandona R, Murthy K, Cowie B, Amare AT, Antonio CA, Castañeda-Orjuela C, van Gool CH, Violante F, Oh IH, Deribe K, Soreide K, Knibbs L, Kereselidze M, Green M, Cardenas R, Roy N, Tillmann T, Li Y, Krueger H, Monasta L, Dey S, Sheikhbahaei S, Hafezi-Nejad N, Kumar GA, Sreeramareddy CT, Dandona L, Wang H, Vollset SE, Mokdad A, Salomon JA, Lozano R, Vos T, Forouzanfar M, Lopez A, Murray C, Naghavi M (2015) The Global Burden of Cancer 2013. JAMA Oncol 1: 505-527. http://dx.doi.org/doi:10.1001/ jamaoncol.2015.0735

Hansch C, Verma RP (2007) 20-(S)-camptothecin analogues as DNA topoisomerase I inhibitors: a QSAR study. Chem Med Chem 2: 18071813. http://dx.doi.org/10.1002/cmdc.200700138

Jemal A, Bray F, Center MM, Ferlay J, Ward E, Forman D (2011) Global cancer statistics. CA-A Cancer J Clin 61(2): 69-90. http:// dx.doi.org/10.3322/caac. 20107

Latosinska JN, Latosinska M (2013) Anticancer drug discovery — from serendipity to rational design. Drug Discovery. Hany El-Shemy. ISBN 978-953-51-0906-8 http://cdn.intechopen.com/pdfs-wm/41943.pdf

Li HJ, Li XJ, Bai ML, Suo YE, Zhang GH, Cao XY (2015) Matrine inhibited proliferation and increased apoptosis in human breast cancer MCF-7 cells via upregulation of Bax and downregulation of Bcl-2. Int J Clin Exp Pathol 8: 14793-14799

Li K, Li Y, Zhou D, Fan Y, Guo H, Ma T, Wen J, Liu D, Zhao L (2016) Synthesis and biological evaluation of quinoline derivatives as potential anti-prostate cancer agents and Pim-1 kinase inhibitors. Bioorg Med Chem 24: 1889-1897. http://dx.doi.org/10.1016/j. bmc.2016.03.016.

Lorente A, Vázquez Y, Fernández MJ, Ferrández A (2004) Bisacridines with aromatic linking chains. Synthesis, DNA interaction, and antitumor activity. Bioorg Med Chem 12: 4307-4312 http://dx.doi. org/10.1016/j.bmc.2004.06.021

Ma WW, Adjei AA (2009) Novel agents on the horizon for cancer therapy. CA-A Cancer J Clin 59: 111-137. http://dx.doi.org/111137. $10.3322 /$ caac. 20003

Ming J, Ruan S, Wang M,Ye D, Fan N, Meng Q, Tian B, Huang T (2015) A novel chemical, STF-083010, reverses tamoxifen-related drug resistance in breast cancer by inhibiting IRE1/XBP1. Oncotarget 6: 40692-40703. http://dx.doi.org/10.18632/oncotarget.5827

Nawrot-Modranka J, Nawrot E, Graczyk J (2006) In vivo antitumor, in vitro antibacterial activity and alkylating properties of phosphorohydrazine derivatives of coumarin and chromone. Eur I Med Chem 41:1301-1309. http://dx.doi.org/10.1016/j.ejmech.2006.06.004

Piastowska-Ciesielska AW, Kozlowski M, Wagner W, Dominska K, Ochedalski T (2013) Effect of an angiotensin II type 1 receptor blocker on caveolin-1 expression in prostate cancer cells. Arch Med Sci 9: 739-744. http://dx.doi.org/10.5114/aoms.2012.30955

Rescifina A, Zagni C, Varrica MG, Pistara V, Corsaro A (2014) Recent advances in small organic molecules as DNA intercalating agents: synthesis, activity, and modeling. Eur J Med Chem 74: 95-115. http://dx.doi.org/10.1016/j.ejmech.2013.11.029

Rawat RP, Verma SM (2016) Design and synthesis of chroman derivatives with dual anti-breast cancer and antiepileptic activities. Drug Des Devel Ther 10: 2779-2788. https://doi.org/10.2147/DDDT. S111266

Sahu U, Sidhar H, Ghate PS, Advirao GM, Raghavan SC, Giri RK (2013) A novel anticancer agent, 8-methoxypyrimido[4',5':4,5] thieno $(2,3-b)$ quinoline-4(3H)-one induces neuro $2 \mathrm{a}$ neuroblastoma cell death through P53-dependent, caspase-dependent and -independent apoptotic pathways. PLOS One 8: e66430. http://dx.doi. org/10.1371/journal.pone.0066430

Saleh AM, Aljada A, El-Abadelah MM, Sabri SS, Zahra JA, Nasr A, Aziz MA (2015a) The pyridone-annelated isoindigo $(5$ '-Cl) induces apoptosis, dysregulation of mitochondria and formation of ROS in leukemic HL-60 cells. Cell Physiol Biochem 35: 1958-1974. http:// dx.doi.org/10.1159/000374004

Saleh AM, El-Abadelah MM, Aziz MA, Taha MO, Nasr A, Rizvi SA (2015b) Antiproliferative activity of the isoindigo 5'-Br in HL-60 cells is mediated by apoptosis, dysregulation of mitochondrial functions and arresting cell cycle at G0/G1 phase. Cancer Lett 361: 251261. http://dx.doi.org/10.1016/j.canlet.2015.03.013 
Sampson N, Neuwirt H, Puhr M, Klocker H, Eder IE (2013) In vitro model systems to study androgen receptor signaling in prostate cancer. Endocr Relat Cancer 20: R49-R64. http://dx.doi.org/10.1530/ ERC-12-0401

Siegel R, Naishadham D, Jemal A (2013) Cancer statistics, 2013. CA-A Cancer J Clin 63: 11-30. http://dx.doi.org/10.3322/caac.21166

Siegel RL, Miller KD, Jemal A (2016) Cancer statistics, 2016. CA-A Cancer I Clin 66: 7-30. http://dx.doi.org/10.3322/caac.21332

Szulawska-Mroczek A, Szumilak M, Szczesio M, Olczak A, Nazarski RB, Lewgowd W, Czyz M, Stanczak A (2013) Synthesis and biological evaluation of new bischromone derivatives with antiproliferative activity. Arch Pharm 346: 34-43. http://dx.doi.org/10.1002/ $\operatorname{ardp} .201200220$

Szumilak M, Szulawska-Mroczek A, Koprowska K, Stasiak M, Lewgowd W, Stanczak A, Czyz M (2010) Synthesis and in vitro biological evaluation of new polyamine conjugates as potential anticancer drugs. Eur J Med Chem 45: 5744-5751. http://dx.doi.org/10.1016/j. ejmech.2010.09.032

Taher AT, Hegazy GH (2013) Synthesis of novel bis-anthraquinone derivatives and their biological evaluation as antitumor agents. Arch Pharm Res 36: 573-578. http://dx.doi.org/10.1007/s12272-0130074-x

Trathnigg B, Golob K, Junek H, Popitsch A (1985) Chelating enaminoketones, II. Syntheses of symmetric ligands. Monatsh Chem 116: 323-339
Tse WC, Boger DL (2004) Sequence-selective DNA recognition: natural products and nature's lessons. Chem Biol 11: 1607-1617. http:// dx.doi.org/10.1016/j.chembiol.2003.08.012

Walczak JR, Carducci MA (2007) Prostate cancer: a practical approach to current management of recurrent disease. Mayo Clin Proc 82: 243 249. http://dx.doi.org/10.4065/82.2.243

Wojciechowska U, Didkowska J (2013) Illness and deaths from malignant tumors in Poland. National Cancer Registry, Cancer Centre - Institute for them. Maria Sklodowska-Curie. ISSN 0867-8251 http://onkologia.org.pl/wp-content/uploads/BIUL 2013.pdf

Xiong P, Wang R, Zhang X, DeLa TE, Leon F, Zhang Q, Zheng S, Wang G, Chen QH (2015) Design, synthesis, and evaluation of genistein analogues as anti-cancer agents. Anticancer Agents Med Chem 15: 1197-1203. http://dx.doi.org/10.2174/187152061566615052014243 7

Xu L, Farmer R, Huang X, Pavese J, Voll E, Irene O, Biddle M, Nibbs A, Valsecchi M, Scheidt K, Bergan R (2010) Discovery of a novel drug KBU2046 that inhibits conversion of human prostate cancer to a metastatic phenotype. Cancer Prev Res 3 (12 Suppl): B58 http://dx.doi.org /10.1158/1940-6207.PREV-10-B58 